San Antonio Review • San Antonio Review (Volume V | Summer 2021)

\title{
Seven Short Book Reviews
}

\author{
Ash Lange
}

Published on: Jul 07, 2021

License: Creative Commons Attribution 4.0 International License (CC-BY 4.0). 
Reading, rereading or sanitising and forcing upon the random strangers who are now forced, once more, to interact.

Nancy Tucker, The First Day of Spring: A well-crafted debut novel that puts us inside the mind of a young single mother. Who happens to have murdered another child when she was eight. Puts the reader in mind of several famous cases, but deftly sidesteps any comparisons to exploitative, lurid, ripped-from-the-headlines pulp.

Daniel KehImann, Ty $\underline{\text { II: }}$ translated fluidly from the German, Kehlmann's novel will soon be getting its own series by the people behind Netflix's Dark. Read it before then, and enjoy the intricately reconstructed world of Tyll Eulenspiegel, medieval German folk anti-hero.

Etgar Keret, The Girl on the Fridge: Keret doing when Keret does best. Short, stinging, and occasionally absurd. But even at his most outlandish, there is always something undeniable human and humane in each of his stories. Equally to be recommended is his collection Fly Already.

Herman Hesse, Knulp: For that friend of yours that can never quite settle down. You know the one.

Hilary Mantel, Giving_Up The Ghost: perhaps to be read in tandem with Elinor Cleghorn's recent Unwell Women, as the most striking passages in this book deal with physical health and the mental toll caused by the disbelief in the illness and pain suffered by women.

Max Porter, The Death of Francis Bacon: Abstract, disjointed, and moving in its depiction of ultimate loneliness.

Adania Shibli, A Minor Detail: An important - and timely - book from last summer, made all the more relevant by this spring's violence in Israel and Palestine. One foot in the past and one foot in the present.

Ash Lange is San Antonio Review's Prose Editor. 